\title{
PREVENTING ECTOPARASITE INFESTATIONS REDUCES GLUCOCORTICOID CONCENTRATIONS IN THE HAIR OF COWS - SHORT COMMUNICATION
}

\author{
Sreten Nedić ${ }^{1}$, Danijela KIROVSKI ${ }^{2}$, Ivan VuJANAC ${ }^{1}$, Radiša ProdANOvić ${ }^{1}$, \\ Ljubomir JovANOVIĆ ${ }^{2}$, Silvestra KOBAL ${ }^{3}$ and Tomaž $\mathrm{SNOJ}^{3 *}$ \\ ${ }^{1}$ Department of Ruminant and Swine Diseases and ${ }^{2}$ Department of Physiology and \\ Biochemistry, Faculty of Veterinary Medicine, University of Belgrade, Belgrade, Serbia; \\ ${ }^{3}$ Institute of Preclinical Sciences, Veterinary Faculty, University of Ljubljana, \\ Gerbičeva 60, 1000 Ljubljana, Slovenia
}

(Received 12 December 2017; accepted 25 July 2018)

\begin{abstract}
The aim of this study was to compare hair corticosteroid concentrations in ectoparasiticide-treated $(\mathrm{n}=10)$ and non-treated $(\mathrm{n}=12)$ Holstein cows. Animals in the treated group received cyfluthrin three times, on days 0,28 and 56 of the experiment. Hair samples were collected from all cows on days $0,21,42,63$, and 84 of the experiment for the determination of cortisol and corticosterone concentrations using immunoassays. The respective hair cortisol concentrations in the treated group averaged 209.78, 165.10, 260.78, 177.44 and $183.11 \mathrm{ng} / \mathrm{g}$, while in the non-treated group hair cortisol concentrations averaged 172.58, 243.58, $309.73,199.75$ and $207.09 \mathrm{ng} / \mathrm{g}$. These results indicate that the control of ectoparasites reduced hair cortisol levels in dairy cows. The respective hair corticosterone concentrations in the treated group averaged 19.06, 22.95, 21.95, 21.60 and $24.84 \mathrm{ng} / \mathrm{g}$ and in the non-treated group the hair corticosterone concentrations averaged $17.28,21.94,34.05,26.27$ and $26.91 \mathrm{ng} / \mathrm{g}$. The results suggest that longterm stress can be estimated better by the determination of hair cortisol rather than corticosterone concentrations.
\end{abstract} hair

Key words: Corticosteroids, long-term stress, dairy cows, ectoparasiticides,

In the warm seasons, control of ectoparasites is recommended in dairy cattle. Several ectoparasiticides are used for this purpose (Taylor, 2001), although pour-on pyrethroids are the most common. Ectoparasites are factors which commonly cause chronic stress reaction in cases of long-term exposure (Baldacchino et al., 2013). Stress enhances acute (Kovács et al., 2016) and chronic (Kovács et al., 2015) hypothalamus-pituitary-adrenal axis (HPA) responses in cattle, resulting in increased corticosteroid secretion from the adrenal cortex. Cortisol concentrations in the blood, saliva, and milk reflect short-term (Queyras and Carosi,

“Corresponding author; E-mail: tomaz.snoj@vf.uni-lj.si; Phone: 00386 (1) 4779-130 
2004), whereas cortisol concentrations in the hair reflect long-term HPA activity (Meyer and Novak, 2012). The aim of this study was to compare hair cortisol and corticosterone concentrations in ectoparasiticide-treated and non-treated dairy cows. Additionally, a method for the identification of long-term stress based on the determination of cortisol level in the hair was established.

The experiment was approved by the Ethics Committee of the Faculty of Veterinary Medicine, University of Belgrade (number 01-19/4). The study was performed at a dairy farm in Belgrade, Serbia, located at coordinates $44^{\circ} 49^{\prime} 14^{\prime \prime}$ North and $20^{\circ} 27^{\prime} 44^{\prime \prime}$ East, from July to September 2014. The environmental conditions driving heat stress are presented using the temperature-humidity index (THI), which combines the effects of environmental temperature with relative humidity. Average temperature in July and August was $23.2{ }^{\circ} \mathrm{C}$ and THI was 78.8, while in September average temperature was $18.1^{\circ} \mathrm{C}$ and THI was 66.7. Twenty-two healthy mid-lactating Holstein cows aged 4 to 8 years, with similar milk production in the previous lactation, were selected for the study. All selected cows were maintained under a loose housing system, fed a total mixed ration twice a day and provided with drinking water ad libitum. The animals were divided into a treated group $(\mathrm{n}=10)$ and a non-treated $(\mathrm{n}=12)$ group that were housed separately in the same stall. The cows from the treated group were initially treated with the pyrethroid ectoparasiticide cyfluthrin (Bayofly pour-on, Bayer, Berlin, Germany). Ten $\mathrm{mL}$ of the drug was applied to the cow's back. The treatment was repeated after 28 and 56 days. Hair samples $(0.5 \mathrm{~g})$ were collected before initial treatment on day 0 (S0), and 21 (S1), 42 (S2), 63 (S3) and 84 (S4) days after the first treatment, meaning that S0, S1 and S2 were performed during July and August while S3 and S4 in September. Each hair sample was obtained from the middle part of the tail using an electric hair clipper. The samples were stored at $-20{ }^{\circ} \mathrm{C}$ until analysis. Prior to the measurement cortisol and corticosterone were extracted from the hair with methanol as described by Nedić et al. (2017). Cortisol and corticosterone concentrations in the hair extracts were determined using commercial ELISA kits (Demeditec, Kiel-Walsee, Germany). Partial validations of hair cortisol and corticosterone detection were performed (Nedić et al., 2017).

Data were analysed using the Statistica v.8 commercial software (StatSoft, Inc., Tulsa, OK, USA). The normality of data distribution was tested using the Shapiro-Wilk test. Significant differences were determined by a mixed betweenwithin design ANOVA model with two factors, using Fisher LSD post hoc test. Statistical significance was considered at $\mathrm{P}<0.05$.

No differences were found in hair corticosteroid levels between the treated and non-treated animals in samples at day 0 prior to the ectoparasiticide treatment $(\mathrm{P}=0.31)$, suggesting that the incorporation and loading intensity of these hormones into the hair before S0 were equal in both groups, probably due to their exposure to the same environmental conditions. However, in S1 and S2, the 
hair cortisol concentrations in the treated group were significantly lower than the concentrations in the non-treated group (Table 1). This result indicates that the ectoparasiticide decreased long-term stress caused by ectoparasites in the warmest period of the year and thus influenced the HPA activity. No significant differences in cortisol concentrations in the hair between groups were found in sampling periods $\mathrm{S} 3(\mathrm{P}=0.29)$ and $\mathrm{S} 4(\mathrm{P}=0.31)$, probably because the temperature was lower than in the previous periods and, consequently, there was a decreased ectoparasite infestation.

Table 1

Cortisol and corticosterone concentrations in the hair of non-treated $(\mathrm{n}=12)$ and cyfluthrin-treated cows $(\mathrm{n}=10)$

\begin{tabular}{lccccc}
\hline $\begin{array}{l}\text { Days } \\
\text { after } \\
\text { the first } \\
\text { treatment }\end{array}$ & $\begin{array}{c}\text { Non-treated group } \\
\text { Mean } \pm \text { SE }\end{array}$ & $\begin{array}{c}\text { Created group } \\
\text { Mean } \pm \text { SE }\end{array}$ & & $\begin{array}{c}\text { Non-treated group } \\
\text { Mean } \pm \text { SE }\end{array}$ & $\begin{array}{c}\text { Treated group } \\
\text { Mean } \pm \text { SE }\end{array}$ \\
\hline 0 & $172.58 \pm 24.45^{\mathrm{aA}}$ & $209.78 \pm 25.60^{\mathrm{aAB}}$ & & $17.28 \pm 1.33^{\mathrm{cA}}$ & $19.06 \pm 1.08^{\mathrm{cA}}$ \\
21 & $243.58 \pm 28.16^{\mathrm{aAB}}$ & $165.10 \pm 14.05^{\mathrm{bA}}$ & & $21.94 \pm 2.04^{\mathrm{cB}}$ & $22.95 \pm 0.91^{\mathrm{cA}}$ \\
42 & $309.73 \pm 14.14^{\mathrm{aB}}$ & $260.78 \pm 13.08^{\mathrm{bB}}$ & & $34.05 \pm 2.63^{\mathrm{cC}}$ & $21.95 \pm 0.97^{\mathrm{dA}}$ \\
63 & $199.75 \pm 13.07^{\mathrm{aA}}$ & $177.44 \pm 16.24^{\mathrm{aA}}$ & & $26.27 \pm 1.91^{\mathrm{cC}}$ & $21.60 \pm 1.91^{\mathrm{cA}}$ \\
84 & $207.09 \pm 11.67^{\mathrm{aA}}$ & $183.11 \pm 21.02^{\mathrm{aA}}$ & & $26.91 \pm 2.17^{\mathrm{cB}}$ & $24.84 \pm 1.31^{\mathrm{cA}}$ \\
\hline
\end{tabular}

${ }^{a, b}$ Cortisol concentrations in the same rows with different superscripts differ significantly $(\mathrm{P}<$ $0.05) ;{ }^{c, d}$ corticosterone concentrations in the same rows with different superscripts differ significantly $(\mathrm{P}<0.01)$; ${ }^{\mathrm{A}, \mathrm{B}, \mathrm{C}}$ cortisol or corticosterone concentrations in the same columns with different superscripts differ significantly $(\mathrm{P}<0.01)$

The corticosterone concentration in the treated group was significantly lower only in S2, in the hottest period of the year, when the maximal daily temperature was $29.3^{\circ} \mathrm{C}$. This suggests that corticosterone loading into the hair is less intensive than cortisol loading, particularly if the corticosterone/cortisol ratio in the blood is considered. As described by Venkataseshu and Estergreen (1970), the serum corticosterone/cortisol ratio is around 1:4. In this study the corticosterone/ cortisol ratio ranged between 1:7.6 and 1:11.5. This suggests that the hair's corticosterone accumulation dynamics are less intense than its cortisol accumulation dynamics. Additionally, high hair cortisol and corticosterone levels were determined in S2, which was performed in the middle of August. In both the treated and the non-treated groups, the cortisol and corticosterone values were significantly higher than the values obtained in the previous samples. This finding may be due to heat stress $\left(\mathrm{THI}_{\max }=83.3\right)$, since sampling was performed during the 
hottest season. The hair cortisol and corticosterone concentrations at S2 were significantly lower in both groups, indicating that despite the elevated temperatures, the treated animals were effectively protected from ectoparasites and thus were exposed to lower degrees of stress. Since after the first treatment with ectoparasiticide the hair cortisol levels were higher in the non-treated cows than in the treated ones, we presumed that hair cortisol level is a useful indicator of chronic stress.

\section{Acknowledgements}

This work was financially supported by The Slovenian Research Agency (grant number P4-0053) and the Ministry of Education, Science and Technological Development, Republic of Serbia (project number III 46002). We thank Katarina Babnik and Boštjan Drolc for their technical assistance. The text was language-edited by American Journal Experts.

\section{References}

Baldacchino, F., Muenworn, V., Desquesnes, M., Desoli, F., Charoenviriyaphap, T. and Duvallet, G. (2013): Transmission of pathogens by Stomoxys flies (Diptera, Muscidae): a review. Parasite 20, 26.

Kovács, L., Kézér, F. L., Jurkovich, V., Kulcsár-Huszenicza, M. and Tőzsér, J. (2015): Heart rate variability as an indicator of chronic stress caused by lameness in dairy cows. PLoS ONE 10 (8): e0134792. doi:10.1371/journal.pone.0134792.

Kovács, L., Kézér, F. L., Kulcsár-Huszenicza, M., Ruff, F., Szenci, O. and Jurkovich, V. (2016): Hypothalamic-pituitary-adrenal and cardiac autonomic responses to transrectal examination differ with behavioral reactivity in dairy cows. J. Dairy Sci. 99, 7444-7457.

Meyer, S. J. and Novak, A. M. (2012): Minireview: Hair cortisol: A novel biomarker of hypothalamic-pituitary-adrenocortical activity. Endocrinology 153, 4120-4127.

Nedić, S., Pantelić, M., Vranješ-Đurić, S., Nedić, D., Jovanović, L., Čebulj-Kadunc, N., Kobal, S., Snoj, T. and Kirovski, D. (2017): Cortisol concentrations in hair, blood and milk of Holstein and Busha cattle. Slo. Vet. Res. 54, 163-172.

Queyras, A. and Carosi, M. (2004): Non-invasive techniques for analysing hormonal indicators of stress. Ann. Ist. Super. Sanità. 40, 211-221.

Taylor, M. A. (2001): Recent developments in ectoparasiticides. Vet. J. 161, 253-268.

Venkataseshu, G. K. and Estergreen, V. L. Jr. (1970): Cortisol and corticosterone in bovine plasma. J. Dairy Sci. 53, 480-483. 